\title{
Silaj Mikro Florasının Birbirleri İle İlișkileri, Silaj Fermentasyonu ve Kalitesi Üzerine Etkileri
}

\author{
Mustafa KIZILSIMSEK ${ }^{1 *}$, Adem EROL ${ }^{1}$, İbrahim ERTEKİ ${ }^{2}$, Rukiye DÖNMEZ $^{2}$, Bedir KATRANCI ${ }^{2}$ \\ ${ }^{1} \mathrm{KSU}$, Ziraat Fakültesi, Tarla Bitkileri Bölümü, Kahramanmaras \\ ${ }^{2}$ KSÜ, Fen Bilimleri Enstitüsü, Tarla Bitkileri ABD, Kahramanmaras
}

Geliş (Received): 03.03.2016

Kabul (Accepted): 12.04.2016

\begin{abstract}
ÖZET: Ülkemizde silaj yapımı son yıllarda giderek artan bir hızla yaygınlaşmaktadır. Silaj yapımının tekniğine uygun şekilde yapılması, üstün kaliteli silaj elde edilmesi için bir ön şarttır. Bununla birlikte silaj mikro florası, bunların birbirleri ile ilişkileri ve silo içerisindeki gelişimleri, silaj kalitesini belirleyen ana unsurlardan biridir. Ancak, ülkemizde silaj yapımı ile ilgilenen işletmelerin önemli bir çoğunluğu, bilgi eksikliği, dikkatsizlik veya önemsememe gibi nedenlerle, bu konuya gereken önemi vermedikleri için, silaj kalitesinde önemli kayıplar yaşanabilmekte ve silajın aerobik stabilitesinde azalmalar görülmektedir. Bazen bu yanlış uygulamaların sonucunda hayvan sağlığı tehdit edilmekte veya hayvansal ürünlerde de kalite kayıpları yaşanmaktadır. Silaj yapımında uygun teknikleri uygulayabilmek için, silaj mikro florasının davranışlarını ve sonuçlarını bilmek büyük öneme sahiptir. Bu makalede, literatür bilgilerine göre, silaj içerisindeki mikro floranın genel durumu, birbirleri ile ilişkileri, fermentasyon yönü ve silaj kalitesine etkileri incelenmiştir.
\end{abstract}

Anahtar Kelimeler: Silaj, Mikro flora, Mikro organizma, Fermentasyon, Kalite

\section{Relationship Among Silage Micro Flora and Their Effects on Silage Fermentation and Quality}

ABSTRACT: Silage making has become widespread in Turkey gradually in last decade. Applying technically appropriate silage making procedure is prerequisite to obtain high quality silage. In addition, variability of silage micro flora, their relationship among themselves and their growth in silo are main factors affecting silage quality. Nevertheless, due to some reasons such as lack of information, inattention and disregards of majority of corporation interested in silage making, huge losses in quality and decreases in aerobic stability of silage are seen. Sometimes, animal health is threatened and quality losses in animal product can occur as a result of such misapplications. Silage microorganisms and their behavior in silage should be known for applying appropriate techniques in silage making. In this paper, common position of micro flora in silage and their effects on fermentation direction and silage quality will be reviewed based on literature.

Key Words: Silage, Micro flora, Microorganisms, Fermentation, Quality

\section{GíRiş}

Hayvancılık sektörü, gelişmekte olan dünya ülkelerinde, tarımsal ekonominin en hızlı gelişen kolu konumundadır. Ancak bu sektörde üretimi olumsuz etkileyen en önemli faktörün hayvan besleme ile ilgili olduğu kabul edilmektedir. Ayrıca, hayvancilıkla ilgilenen birçok bölgede yem üretimi genellikle yllın belli bir döneminde mümkün olmaktadır. Yılın geri kala kısmında herhangi bir kaba yem üretimi mümkün olmamaktadır. Silaj yapımının ana amacı; taze yem bitkilerinin ve diğer kaba yemlerin kıt olduğu veya otlatmanın yapılamadığı dönemlerde hayvanların kaba yem gereksinimini karş̧lamaktır. Bununla birlikte dünyadaki modern hayvancıllk işletmelerine, yalnızca bu dönemlerde değil, yıl boyu silajla besleme uygulamaları yapılmakta ve hayvan diyetlerinde çeşitli bitki silajlarına yıl boyu yer verilmektedir. Bu şekilde, üretim sisteminin ekonomik ve çevresel olarak sürdürülebilirliğine katkı sağlanmaktadır. Mısır, buğday, fiğ gibi bitkilerin birim alandan ürettikleri sindirilebilir madde veriminin, tüm bitki hasadında (örneğin; silaj için hasat) sadece tane hasadına göre daha yüksek olduğu bildirilmiştir (Driehuis ve ark. 2000). Silajın bir diğer önemli avantajı da, hasattan hayvan beslemeye kadar olan tüm dönemlerinde, özellikle entansif işletmeler için mekanize uygulamalara geniş olanaklar sağlamasıdır.

Mısır, arpa, buğday, sorgum, bazı buğdaygil yem bitkileri, yonca, fiğ ve üçgül gibi farklı bitkiler (Ashbell ve Weinberg, 2006) ile elma (Ajila ve ark. 2012) ve turunçgil posası gibi tarımsal atıklardan silaj yapmak mümkündür. $\mathrm{Bu}$ nedenle silaj hammaddesi oldukça geniş bir yelpazeye yayılmıştır. Silaj hammaddesi ne olursa olsun, bu suca zengin materyali korumanın ve uzun süre saklamanın yolu, anaerobik şartlarda laktik asit fermentasyonunu sağlamaktır (Gollop ve ark. 2005).

\section{SILAJ FERMENTASYON SÜRECI}

Silaj yapımının ana prensibi; anaerobik şartlarda laktik asit fermentasyonu sayesinde silolanmış materyalin $\mathrm{pH}$ seviyesini hızlı bir şekilde düşürmek ve anaerobik şartların devamını sağlamaktır. Silolama süreci dört temel evrede incelenebilir. İlk evre; hasat ile başlayan ve silolamadan sonraki 24-48 saate kadar devam eden ve "aerobik solunum dönemi" diye adlandırılan bir süreçtir. $\mathrm{Bu}$ dönemde hasat edilen ve parçalanan bitki dokusu içerisine atmosferik oksijen rahatlıkla girer ve hem canlı bitki hücrelerinin solunum 
yapması, hem de zorunlu veya fakültatif aerobik mikro organizmaların faaliyetleri sonucu kuru madde kayıpları ortaya çıkar. "Anaerobik fermentasyon dönemi" olarak adlandırılan ikinci evre, silolanan materyal içerisinde mevcut oksijen bittikten sonra başlar ve silolama şartlarına ve silolanan materyalin özelliklerine bağl olarak birkaç gün ile birkaç ay arasında değişen sürelere kadar devam eder. $\mathrm{Bu}$ aşamada farklı mikroorganizma guruplar1 (laktik asit bakterileri (LAB), asetik asit bakterileri, enterobakteriler, klostridia bakterileri, küfler ve mayalar) anaerobik olarak gelişirler ve ortamdaki besin maddeleri için bir rekabete girerler. İyi silolanmış silajlarda LAB hızlı bir şekilde fermentasyonda dominant konuma geçerler ve bu bakteriler bitki şekerlerini (özellikle glikoz, früktoz ve sukroz) kullanarak yüksek miktarda laktik asit, bir miktar da asetik asit üreterek ortamın $\mathrm{pH}$ seviyesini düşürürler. Üçüncü aşama "anaerobik dinlenme dönemi" olarak adlandırılır. $\mathrm{Bu}$ dönem fermentasyon sona erdikten sonra başlayan ve silajın hayvanlara yedirilmesi amacıyla açılmasına kadar geçen süredir. Bu dönem birkaç hafta ile bir yıl arasında değişen sürelerde olabilir ve bu dönemde fermentasyon yok denecek kadar az olduğundan, dinlenme süresi boyunca silajın organik asit kompozisyonunda bir değişim olması beklenmez. Ortam pH seviyesi yeteri kadar düşük olduğu ve dışarıdan oksijen veya su girişine izin verilmediği sürece silaj materyali stabil olarak kalır. Hemen her tür mikroorganizma sayısında önemli azalmalar görülür. Bazı asit tolerant mikroorganizmalar (bazı maya türleri) inaktif konuma geçerler, klostridia ve basili türü bazı mikroorganizmalar spor oluşturarak hayatta kalırlar. Bazı özel mikroorganizmalar (örneğin, Lactobacillus buchneri) düşük miktarlarda aktif olarak kalmaya devam ederler (Driehuis ve ark. 1999). İkinci ve üçüncü aşama boyunca yemdeki protein fraksiyonları, bitki ve mikrobiyel orijinli enzimlerle peptitlere, amino asitlere, aminlere ve amonyağa indirgenirler. Yem değerini düşüren bu protein indirgenmesi olayı "proteolisis" olarak bilinir ve genellikle silajdaki amonyak konsantrasyonu proteolisis seviyesini belirlemede kullanılan bir indikatördür (Driehuis ve Oude Elferink, 2000). Son aşama ise silajın hayvanlara yedirilmek üzere açıldığı ve atmosferik oksijen ile temas ettiği dönem olan "aerobik besleme dönemi"dir. Aslında silaj örtüsündeki yıpranmalar veya kullanılan plastik örtünün oksijen bariyer özelliğinin bulunmaması, diğer bir ifade ile hava geçirmeyen türden olmaması gibi nedenlerle, bu evre silo açılmadan da başlayabilir. $\mathrm{Bu}$ dönemde oksijene maruz kalan silaj materyali, içerisinde bulunan özellikle küfler ve mayaların ikincil fermentasyonu nedeniyle bozulmaya başlar. Aerobik bozulma (aerobic deterioration) olarak bilinen bu olayı asıl başlatan ve sürdüren mikroorganizmaların, öncelikle aside dayanıklı mayalar ve asetik asit bakterileri olduğu bildirilmiştir (Moon ve Ely, 1979; Oldenburg, 2000). Bu mikroorganizmaların silaj içerisindeki koruyucu asitleri okside ettikçe, silaj içinde
pH yükselir ve diğer istenmeyen mikroorganizmalar da gelişmeye başlarlar (Woolford, 1990).

\section{SILAJ MIKRO FLORASI VE FERMENTASYONDAKİ ROLLERI}

Silaj mikro florası silajdan başarılı fermentasyon çıktıları elde etmede kilit bir rol oynamaktadır. Genel olarak mikroorganizma floras1, istenilen ve istenmeyen mikroorganizmalar olarak iki temel kısma ayrılır. Silaj içerisinde istenilen mikroorganizmalar temel olarak LAB'dir. Bu bakteriler, metabolik ürünleri olan laktik asit sayesinde silajın korunmasını sağlarlar. İstenmeyen mikroorganizmalar ise anaerobik bozulmadan (klostridia ve enterobakteriler gibi) ve aerobik bozulmadan (mayalar, küfler ve listeria gibi) sorumludurlar. Silajın bozulmasina neden olan bu mikroorganizmalar yalnızca silajın besleme değerini düşürmekle kalmaz, aynı zamanda hayvan sağlığı ve hayvansal ürün kalitesini de önemli ölçüde düşürürler (Driehuis ve Oude Elferink, 2000).

\section{Laktik Asit Bakterileri (LAB)}

Laktik asit bakterilerinin kaynağı, bitki materyali üzerindeki epifitik flora olup, onun da asıl kaynağı topraktır. Bitki üzerindeki LAB yoğunluğu, bitkinin kuru madde içeriğine, bitkinin gelişme dönemine, yapraklar üzerindeki besin maddesi varlığına, toprak özelliklerine, rakıma ve iklim şartları gibi daha bir çok faktöre göre değişkenlik göstermektedir. Besin istekleri nedeniyle LAB besince zenginleştirilmiş besi ortamlarında kültüre alınabilir ve süt ve süt ürünleri, et ve et ürünleri ve tahıl ürünleri gibi bir çok ortamda gelişebilirler (Carr ve ark. 2002). Ayrıca insanda koltuk altı, ağız içi, genital bölgeler ile gastro-intestinal organlarda da yoğun şekilde bulunabilirler. Ancak, genellikle patojen olmadıklarından herhangi bir hastalık etmeni sayılmazlar.

Silaj ile ilişkili olan LAB türleri genellikle Lactobacillus, Pediococcus, Leuconostoc ve Enterococcus cinslerine aittir (McDonald ve ark. 1991). Bunun dışında Lactococcus ve Streptococcus cinsleri de bazı önemli LAB türlerini içinde barındırır. $\mathrm{Bu}$ bakteriler $20-40^{\circ} \mathrm{C}$ sıcaklıklarda gelişebilirler. Optimum gelişme sıcaklıkları $32-35^{\circ} \mathrm{C}$ civarındadır. LAB'ni diğerlerinden ayıran en önemli özellikleri, asit ortamlara gösterdikleri toleranstır. $\mathrm{Bu}$ bakteriler silaj $\mathrm{pH}$ seviyesini 4 veya daha aşağı sınırlara kadar düşürebilirler. Bütün LAB türleri seçici aerobik türler olmalarına karşın, bazıları anaerobik şartları daha çok tercih ederler. Şeker metabolizmalarına göre LAB, zorunlu homofermentatif, seçici heterofermentatif veya zorunlu heterofermentatif olmak üzere üçe ayrilır. Zorunlu homofermentatif LAB heksozları EmbdenMeyerhof glikolitik yolu kullanarak \%85'in üzerinde bir oranda laktik aside fermente ederler (Limsowtin ve ark. 2003). Teorik olarak bu fermentasyonla 1 molekül glikozdan 2 molekül laktik asit üretilir ve 2 ATP kazanılır. Ancak bu grup bakteriler fosfoketolaz enzimine sahip olmadıkları için pentozları fermente 
edemezler. İkinci gurup olan seçici heterofermentatif LAB, hem heksozlar1, hem de aldolaz ve fosfoketolaz enzimlerine sahip oldukları için, pentozları fermente edebilirler. Seçici heterofermentatifler glikozu fermente etmede, zorunlu homofermentatif bakteriler ile aynı yolu takip ederlerken, pentozların fermentasyonunda, fosfoketolaza bağımlı yolu (phosphoketolase-dependent pathway) izlerler (Panesar ve ark. 2007). Pentozların fosfoketolaza bağımlı yol ile fermente edilmesinde her bir pentoz molekülünden 1 molekül laktik asit ile birlikte 1 molekül asetik asit veya 1 molekül etanol üretilir. $\mathrm{Bu}$ nedenle laktik asit ile birlikte pentozların fermentasyonundan özellikle asetik asit ve/veya etanol üretimi de gerçekleşir. Zorunlu heterofermentatif türler şeker metabolizmasında, hem heksozlar hem de pentozlar için yalnızca fosfoketolaza bağımlı yolu takip ettiklerinden, laktik asitle birlikte önemli miktarda asetik asit ve/veya etanol ile birlikte karbon dioksit üretimi de gerçekleştirirler (Axelsson, 2004). Bazı yaygın LAB türlerinin şeker metabolizmasına göre sınıflaması Çizelge 1'de verilmiştir.

Çizelge 1. Yaygın olarak görülen bazı LAB türlerinin fermentasyon özelliklerine göre sınıflandırılması

\begin{tabular}{lll}
\hline \multicolumn{1}{c}{ Zorunlu Homolaktik Fermentatif } & \multicolumn{2}{c}{ Seçici } \\
\cline { 2 - 3 } & \multicolumn{1}{c}{ Zorunlu } \\
\hline L. acidophilus & L. plantarum & L. brevis \\
L. helveticus & L. rahamnosus & L. buchneri \\
L. delbrueckii subsp. delbrueckii & L.coryneformis & L. fermentum \\
L. delbrueckii subsp. lactis & L.curvatus & L. kefir \\
L. delbrueckii subsp. bulgaricus & L.casei & L. reuteri \\
Lactococcus lactis & L.paracasei & Leuconostoc sp. \\
Streptococcus thermophilus & & \\
\hline
\end{tabular}

(Kaynak: Cury ve Crow, 2003)

LAB'nin salgıladıkları bazı ürünlerin, diğer mikroorganizmaların gelişimini olumsuz yönde etkilediği, yani antimikrobiyel bir etkiye sahip olabilecekleri bilinmektedir. Magnusson ve ark (2003)'e göre, LAB'nin antimikrobiyel etkinlikleri üç şekilde açıklanabilir; I-üretilen organik asit miktarı, IIbesin maddesi yönünden rekabetleri ve III- ürettikleri antagonistik bileşikler. Antimikrobiyel etkinliği sağlayan antagonistik bileşik üretimi LAB için yaygın bir durum olmadığından, bu güne kadar örneğin küfler üzerinde etkili olabilen LAB suşlarından bahseden sadece bir kaç çalışma mevcuttur. Roy ve ark. (1996), izole ettikleri 2100 adet LAB suşunun, değişik küf türlerine karşı antagonistik etkisini araştırmak için incelemişler ve yalnızca 6 LAB kolonisinin tek bir tür (Aspergillus flavus) üzerine etkili olduğunu ve yalnızca 1 LAB kolonisinin daha geniş spektrumlu bir etkiye sahip olduğunu belirlemişlerdir. Araştırıcılar bu izolatı L. lactis subsp. lactis olarak teşhis etmişlerdir.

Birçok çevresel faktör LAB'nin gelişimini etkilemektedir. Bunların başında sıcaklık gelir. Genelde $\mathrm{LAB} 20-40^{\circ} \mathrm{C}$ arasında gelişme gösterseler de, geliştikleri optimum sicaklıklara göre mezofilik gruplara ayrılırlar. Örneğin $L$. delbrueckii, $L$. delbrueckii subsp. bulgaricus (L. bulgaricus), $L$. thermophilus, ve $L$. delbrueckii gibi türlerin optimum gelişme sıcaklıkları daha yüksek olduğundan, termofilik bakteriler grubuna girerler (Panesar ve ark. 2007).

Yeşil bitkiler üzerindeki epifitik flora, çok sayıda mikroorganizma türünü barındırmaktadır. Ancak silaj yapımında yalnızca bazı türler ön plana çıkmaktadır. Silaj yapımında önem arz eden türler ve bitkilerdeki ortalama miktarları Çizelge 2'de verilmiştir.
Çizelge 2. Bitkiler üzerinde bulunan bakteri ve fungal gurupların tipik dağılımı ve miktarları

\begin{tabular}{ll}
\hline \multicolumn{1}{c}{ Mikroorganizma Gurubu } & \multicolumn{1}{c}{$\begin{array}{c}\text { Populasyonu } \\
\left(\mathrm{kob}^{*} \mathrm{~g}^{-1} \mathrm{bitki}\right)^{*}\end{array}$} \\
\hline Toplam aerobik bakteri & $>10.000 .000$ \\
Laktik asit bakterileri & $10-1.000 .000$ \\
Enterobakteriler & $1.000-1.000 .000$ \\
Maya ve maya benzeri funguslar & $1.000-100.000$ \\
Küfler & $1.000-10.000$ \\
Clostridia (endospor) & $100-1.000$ \\
Bacili (endospor) & $100-1.000$ \\
Asetik asit bakterileri & $100-1.000$ \\
Propiyonik asit bakterileri & $10-100$ \\
\hline
\end{tabular}

*:Koloni oluşturan birim

Çizelge 2'den görüldüğü üzere silaj yapımı öncesi bitkiler üzerinde bulunan ve silaj kalitesini etkileme yeteneğinde olan bir çok mikroorganizma gurubu vardır. $\mathrm{Bu}$ gruplar içerisinde özellikle mayalar, küfler, enterobakteriler ve klostridia türleri silaj kalitesini etkileme bakımından ön plana çıkmaktadır.

\section{Mayalar}

Mayalar fakültatif anaerobik, ökaryotik, heterotrofik ve tomurcuklanma ile yayılan mikroorganizmalardır. Mayalar silaj yapımı sırasında, özellikle aerobik solunum döneminde, anaerobik fermentasyon döneminin başlangıcında ve aerobik besleme döneminde faaliyet gösterirler. Her ne kadar silajın aerobik bozulmasından birinci derecede mayalar sorumlu olsalar da, anaerobik şartlar altında da bir çok 
maya türü glikoz, maltoz ve sukroz gibi şekerleri öncelikle etanol ve karbondioksite, az miktarda da diğer alkollere (örneğin propanol, 2-butanediol, pentanol v.d.) ve asetat, propiyonat ve bütrat gibi bazı uçucu yağ asitlerine fermente ederler. Aerobik şartlar altında mayalar laktik asidi okside ederek ortamın $\mathrm{pH}$ seviyesini yükseltir ve silajı bozacak diğer istenmeyen mikroorganizmaları da aktif hale gelmeleri için tetiklerler. Hem aerobik hem de anaerobik şartlardaki maya aktivitesi silaj kalitesi bakımından arzu edilmeyen fermentasyon olarak kabul edilir. Çünkü bu fermentasyon tiplerinde yüksek miktarda kuru madde kaybı gerçekleşir, silaj kötü kokmaya başlar ve bu kötü koku sütte de kendini açıkça gösterir. Ayrıca mayalar silajın aerobik bozulmasını başlatan mikroorganizmaların en önemlisi olarak kabul edilir.

Mayalar anaerobik şartlarda ayrıca laktat üretimi de gerçekleştirirler. Genellikle çok asidik ortama dayanamasalar da Candida, Hansenula, Saccaromyces ve Torulopsis cinslerine ait türlerin bazılarının asit dayanımı yüksektir. Silaj yapımının ilk aşamalarında, özellikle de ilk haftada, mayaların sayısı 107 kob g-1 silaj seviyelerine kadar çıkabilir. Depolama süresi ilerledikçe sayılarında önemli azalmalar görülür. Silajın dinlenme dönemi olan depolama evresinde mayaların hayatta kalması, anaerobik şartların devamlılığına, silajın $\mathrm{pH}$ seviyesine, organik asitlerin konsantrasyonuna ve maya türüne bağlı olarak değişir.

\section{Küfler}

Küfler genellikle aerobik mikroorganizmalar olduklarından, silaj içerisindeki gelişimleri genellikle iyi kapatılmamış veya iyi sıkıştırılmamış siloların yüzey tabakasına yakın kısımlarında gelişme gösterirler. Küfler ayrıca, besleme döneminde silajın aerobik bozulmasında önemli rol oynarlar. Silajlarda en sik rastlanan küfler genellikle Penicilium, Fusarium, Aspergillus, Mucor, Bysochlamys, Absidia, Arthrinium, Geotrichum, Monascus, Scopulariopsis ve Trichoderma cinslerine aittir (Mc Donld ve ark., 1991; Nout ve ark. 1993). Silaj içerisinde bulunan çoğu küfler, hayvanlarda yem tüketiminin azalması, düşük miktarının artması, hormonal dengesizlik ve bağışıklık sisteminin zayıflaması gibi birçok olumsuz duruma neden olan bir veya birkaç mikotosin üretirler. $\mathrm{Bu}$ mikroorganizmaların silaj içerisinde dominant tür haline gelebilme yetenekleri, yüksek karbondioksit konsantrasyonlarına(800 mL L-1), toleransları, yüksek asetik asit seviyelerine $(3.5 \mathrm{pH}$ seviyesinde $15 \mathrm{~g} \mathrm{~kg}$ 1)dayanıklılıkları ve çok düşük $\mathrm{O} 2$ seviyelerinde (1.4 $\mathrm{mL}$ L-1) bile gelişebilmeleri gibi özelliklerinden kaynaklanmaktadır (Lacey, 1989).

\section{Enterobakteriler}

$\mathrm{Bu}$ grup bakterilerin birçoğu seçici anaerobik türler olup, yeşil bitki epifitik florası içerisinde en çok Ervinia herbicola ve Rahnella aquitilis türleri dominant konumda iken, silaj yapımını takip eden kısa süre içerisinde bu türler yerlerini Hafnia alvei, Escherichia coli ve Sterratia fonticola türlerine bırakırlar (Heron ve ark. 1993). Bu türler içerisinde hayvan sağlı̆̆ bakımından en tehlikeli olan tür E.coli'dir. Bu grup bakteriler, silaj yapımının erken dönemlerinde karbonhidratlar bakımından LAB ile rekabete girerler ve bir miktar da amino asitleri parçaladıkları için etanol ve biyojenik amin üretimi de gerçekleştirirler. Bir çok enterobakteri $\mathrm{pH}$ seviyesinin 4.5-5.0 olduğu durumlarda bile yaşamlarını sürdürmezler. Sadece $\mathrm{O} 2$ varlığında bir süre daha yaşayabilirler. Ancak asitliğin hızlı bir şekilde ve yeteri kadar düşmesi ile gelişimleri tamamen durur (Heron ve ark. 1993). Silajın depolama süresince hayatta kalabilen az sayıdaki enterobakteriler aerobik bozulma döneminde tekrar gelişmeye başlarlar ve kısa sürede 108 g-1 silaj seviyelerine kadar çıkabilirler.

\section{Clostridia}

Bu gurup bakteriler Clostridium cinsine ait ve gram pozitif türlerdir. Birçok tür genellikle zorunlu anaerobik olmakla birlikte, O2 varlığına toleransları da oldukça değişkendir. Clostridia bakterileri enerjilerini karbonhidtrat ve protein gibi organik fermentasyon bileşiklerden sağlar. Silaj içerisinde en sik $C$. tyrobutyricum, $C$. butyricum, $C$. sporogenes ve $C$. bifermentansgibi clostridia türleri görülür. Bunlardan ilk ikisi zayıf proteolitik, son ikisi de yüksek proteolitik özellik gösterir. Proteolitik özelliği zayıf olan türler karbonhidratları fermente ederken, yüksek proteolitik özellik gösterenler proteinleri fermente ederler. Karbonhidrat fermentasyonunda butrik asit ve asetik asit son ürün olarak üretilirken, protein fermentasyonununda bu asitlere ilave olarak etanol, isobutrik asit, isovalerik asit NH3 ve amin üretimi de gerçekleşir. Proteolitik özellik gösterenler genellikle $\mathrm{pH}$ seviyesi 5'in altına indiğinde faaliyet göstermezken, $C$. tyrobutyricum türü pH 4.2 seviyesinde bile faaliyet gösterebilir. Silaj içerisinde clostridial fermentasyonu önlemek için, yüksek kuru maddede silolama yapmak, tam havasızlığı sağlayarak $\mathrm{pH}$ seviyesinin hızlı bir şekilde ve yeteri kadar düşmesini sağlamak veya başlangıçta silaja asit ilavesi yapmak gibi bazı önlemler alınabilir.

\section{Basililer}

Basili türleri seçici anaerobik bakterilerdir. Basili içeren silajlar süt kalitesini olumsuz etkileyebilirler. Özellikle Bacillus cereus türü pastörize sütlerin ve süt ürünlerinin bozulmasına ve gida zehirlenmelerine neden olan türdür. Basili türleri çok sayıdaki karbonhidrat kaynaklarını çeşitli organik asitlere (asetik, laktik, butrik asit gibi), etanole, 2-3 butanediol ve gliserol gibi ürünlere fermente edebilirler. Özellikle hayvan gübrelemesi yapılmış bitkilerin kullanıldığı silajlarda 100 kat daha fazla basili olduğu bilinmektedir.

\section{Listeria}

Bazı bakteri türlerini içeren listeria cinsi, seçici anaerobik mikroorganizmalardır. Silajlarda listeria türlerinin görülmesi genellikle aerobik bozulma süreci ile ilgilidir. $\mathrm{Bu}$ cins içerisinde L. monocytogenes türü, 
insan ve hayvanlar için patojenik özellik taşıması ile ön plana çıkmıştır. Koyun ve keçilerde görülen listeriosis hastalığının, bu bakteriyi içeren silajlarla beslemeden kaynaklandığı bilinmektedir. Listeria cinsine giren bakteriler, iyi havasızlığın sağlandığı ve $\mathrm{pH}$ seviyesinin 4.4 değerinin altına düştüğü silajlarda yaşamlarını sürdüremezler.

\section{SONUÇ}

Standart silaj yapım teknikleri arasında bitki seçimi, hasat zamanı, siloyu hızlı doldurma, etkili silaj katkı maddeleri veya mikrobiyel inokulant kullanma, siloyu iyi kapatma, aerobik bozulmaya firsat vermeden hizlı besleme gibi konular sıralanabilir. Pratikte kötü kalite bitkisel materyal ve bazı teknik konuların göz ardı edilmesi gibi aksaklıklar, silaj fermentasyon kalitesinin yeterli olmamasına, silajın depolanma süresinin kısalmasına ve silaj mikro florasının arzu edilmeyen yönde gelişmesine neden olmaktadır. Silaj kalitesi önemli ölçüde farklı mikro flora guruplarının birbirleri ile rekabetine bağlıdır. Yüksek kaliteli silaj elde edilebilmesi için LAB gruplarının silaj içerisinde dominant tür konumuna gelmeleri şarttır. Her ne kadar mayalar silajın aerobik bozulmasından birinci derecede sorumlu olsalar da, hayvan sağlığı bakımından önemli sorunlar ortaya çıkarabilecek başka mikroorganizmalar da aerobik bozulmada ikinci derecede rol alabilir. Bu mikroorganizma gruplarının silaj içerisinde kabul edilebilir sınırlara çekilmesi, silo materyali içerisinde LAB'nin yeterli miktarlara ulaşması ve asitlik derecesini anaerobik şartlarda yeteri kadar düşürmesine bağlıdır. $\mathrm{Bu}$ nedenle silaj yapımı sırasında mikrobiyel inokulant kullanımı başta olmak üzere, LAB sayısını ve gelişimini artıracak önlemlere özel önem verilmelidir.

\section{KAYNAKLAR}

Ajila, C.M., Brar, S.K., Verma, M., Tyagi, D.R., Godbout, S., Valero, J.R. 2012. Bio-processing of agro-byproducts to animal feed. Crit. Rev. Biotechnol., 32(4): 382-400.

Ashbell, G., Weinberg, Z. 2006. Silage production and utilisation. Food and Agriculture Organisation, FAO Electronic Library.

Axelson, L. 2004. Lactic acid bacteria: Classification and Physiology. In Salminen, S., von Wright, A., Ouwehand, A. Eds., Lactic acid bacteria: Microbiological and functional aspects. 1-66. New York, Marcel Dekker, Inc.

Carr, F.J., Chill, D., Maida, N. 2002. The lactic acid bacteria: A literature survey. Critical Reviews in Microbiology, 28: 281-370.

Cury, B., Crow, V. 2003. Lactobacillus casei group. In Rogonski, H., Fuquay, J.W., Fox, F.P. eds.
Encylcopedia of dairy sciences, 3: 1488-1493. London Academic Press.

Driehuis, F. Odue Elferink, S.J.W.H. 2000. The impack of quality of silage on animal health and food safety: A review. Veterinary Qarterly, 22(4): 212-216

Driehuis, F. Odue Elferink, S.J.W.H., and Spoelstra, S.F. 1999. Anaerobik lactic acid degradation in maize silage inoculated with Lactobacillus buchneri inhibits yeast growth and improves aerobic stability. J. Appl. Microbiol. 87: 583-594.

Gollop, N., Zakin, V., Weinberg, Z.G. 2005. Antibacterial activity of lactic acid bacteria included in inoculants for silage and silage treated with theese inoculants. J. Appl. Microbiol., 98:662-666.

Heron, S.J.E., Wilkinson, J.F., Daffus, C.M. 1993. Enterobacteria associated with grass and silages. J. Appl. Bacteriol., 75: 13-17.

Lacey, J. 1989. Pre- and post-harvest ecology of fungi causing spoilage of foods and other stored products. J. Appl. Bacteriol. 67: 11-25.

Limsowtin, g.K.Y., Broome, M.C., Powell, I.B. 2003. Lactic acid bacteria, taxonomy, In Rogonski, H., Fuquay, J.W., Fox, F.P. eds. Encylcopedia of dairy sciences, 3: 2739-2751. London Academic Press.

Magnusson, J., Strömi K., Ross, S., Sjögren, J., Schnürer, J. 2003. Broad and comlex antifungal activity among environmental isolates of lactic acid bacteria. FEMS microbiology Letters, 219: 129-135.

McDonald, P., Henderson, A.R., Heron, S.J.E. 1991. The biochemistry of silage. Marlow: Chalcombe Publications.

Moon, N.J., Ely, L.O. 1979. Identification and properties of yeast associated with deterioration of wheat and alfalfa silages. Mycopathologia, 69: 153156

Nout M.J.R., Bouwmeester, H.M., Haaksma, J., Dijk, H. 1993. Fungal growth in silages of sugarbeet press pulp and maize. J.Agric.Sci., 121:323-326

Oldenburg E., 1991. Mycotoxins in conserved forage. In: Pahlow G. Honig, H. Eds. Forage Conservation Twards 2000, Proceedings European Grassland Federation, Landbauforschung Völkenrode Sonderheft $123 . \quad$ Brounschweig: Bundesforschungsanstalt für Landwirtschaft Braunschweig-Völkenrode, 191-205

Panesar, S.P., Kenedy, J.F., Gandhi, D.N., Bunko, K. 2007. Bioutilisation of whey for lactic acid production. Food Chem. 105: 1-7.

Roy, U., Batish, V.K., Grover, S., Neelakantan, S. 1996. Production of antifungal subtance by Lactococcus lactis subsp. lactis CHD-28.3. International Journal of Food Microbiology, 32: 27-34.

Woolford, M.K. 1990. The detrimental effects of air in silage. J. Appl. Bacteriol., 68: 101-116. 